\title{
A striking increase in rod-cored vesicles in pit cells (natural killer cells) and augmentation of the liver-associated natural killer activity by a streptococcal preparation (OK-432)
}

\author{
Chieko Dan, Kenji Kaneda and Kenjiro WaKe \\ Department of Anatomy, Faculty of Medicine, Tokyo Medical and Dental University, Yushima, Bunkyoku, \\ Tokyo 113, Japan
}

\begin{abstract}
OK-432, a streptococcal preparation, induced a marked increase in the number of rodcored vesicles in pit cells (natural killer cells) of the rat liver. OK-432 enhanced also the liver-associated natural killer activity. OK-432 injected intravenously was incorporated into lysosomes of Kupffer cells. Kupffer cells and pit cells were increased in their number and were in wide contact with each other. Prominent Golgi complex and many rodcored vesicles characterized the actively secreting pit cells. No obvious morphological changes were detected in dense granules in pit cells. It is suggested that the increment of rod-cored vesicles induced by OK-432 is responsible for the augmentation of the liverassociated natural killer activity.
\end{abstract}

Natural killer (NK) cells spontaneously lyse tumor cells (5) and play an important role in the immune mechanism which prevents tumor growth and metastasis $(1,13)$. NK activity is generally monitored in spleen cells and/or in the peripheral blood. However, the exact mechanism of NK activity in the tissue is not known. Recently Wiltrout et al. (15) reported the aug mentation of the liver-associated NK activity by biological response modifiers, such as maleic anhydride divinyl ether and Propionibacterium acnes.

We previously reported that pit cells in the liver, first described by Wisse et al. (16), were identical with large granular lymphocytes (6). As defined morphologically, pit cells adhere to the sinusoid on the luminal side and are characterized by the presence of dense granules and rod-cored vesicles in the cytoplasm $(7,8)$. It is reasonably assumed that pit cells in the liver are associated with NK activity and are stimulated by biological response modifiers. In addition, OK432 has been shown to enhance the NK activity (10) and used as an immunopotentiator and an antitumor agent (14). Accordingly, we examined the effect of OK-432, a streptococcal preparation (a gift from Chugai Pharmaceutical), on pit cells and on the liver-associated NK activity. It will be shown that a dramatic increase in the number of rod-cored vesicles and the development of Golgi complex are correlated with the augmentation of NK activity of the rat liver following administration of OK-432.

Male Wistar rats (6-8 weeks of age) were intravenously injected with $\mathrm{OK}-432(5 \mathrm{KE}) ; 1 \mathrm{KE}$ (klinische Einheit) corresponds to $0.1 \mathrm{mg}$ of dried Streptococci. The liver was sampled 24-36 h after the injection. For electron microscopy, the liver was perfused with a fixative containing $1.5 \%$ glutaraldehyde, $67 \mathrm{mM}$ cacodylate buffer (pH 7.4) and post-fixed in $2 \% \mathrm{OsO}_{4}$ for $2 \mathrm{~h}$. Ultrathin sections were stained with uranyl acetate and lead citrate, and examined in a JEOL $100 \mathrm{CX}$ electron microscope at $100 \mathrm{kV}$. For the measurement of the liver-associated NK activity, non-parenchymal cells from both the control and the OK-432treated animals were obtained by a modification of the collagenase perfusion technique (12). The NK-mediated cytotoxicity against YAC-1 lymphoma cells were tested in a 4 -hour ${ }^{51} \mathrm{Cr}$ release assay (11). The effect of anti-asialo $\mathrm{GM}_{1}$ (Wako Pure Chemical) on the cytotoxicity was also ex- 


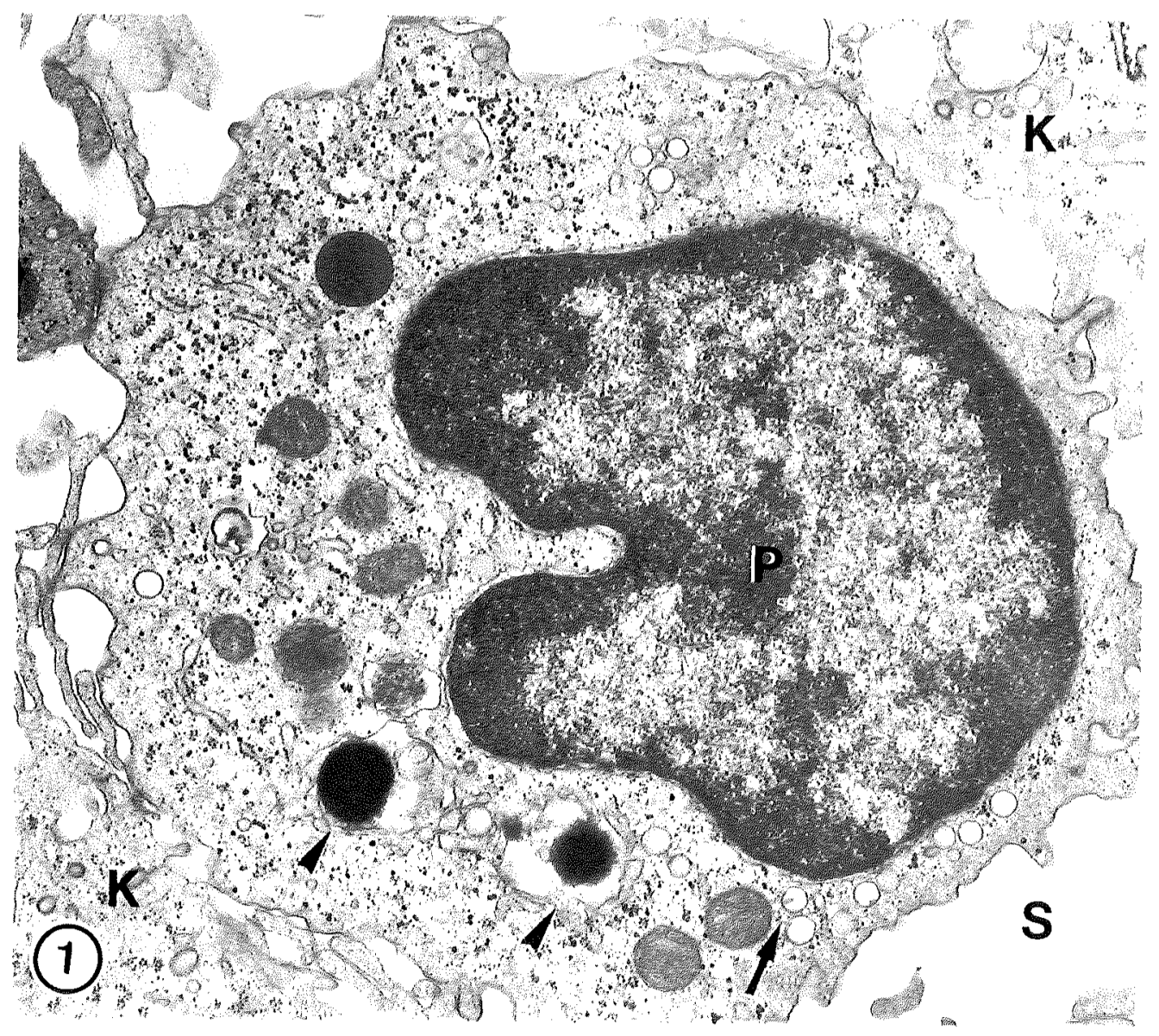

Fig. 1 A pit cell (P) attached to a Kupffer cell (K) in the rat hepatic sinusoid (S) $36 \mathrm{~h}$ after the intravenous injection of OK-432. Rod-cored (arrow) and clear vesicles are increased in number. Note the characteristic dense granules (arrowheads) and the enriched glycogen particles. $\times 15,000$

amined to analyse the specificity of the NKmediated cytotoxicity (9).

OK-432 was trapped by Kupffer cells within 5 min after the injection, and digested by lysosomes $24-36 \mathrm{~h}$ later. Kupffer cells and pit cells were increased in number especially in the periportal area. Some pit cells were in a wide contact with Kupffer cells (Fig. 2), and some migrated into the space of Disse. Pit cells in OK-432-treated rats contained well-developed rough-surfaced endoplasmic reticulum, numerous free ribosomes, and increased glycogen particles in the cytoplasm (Fig. 1). Characteristically, rod-cored vesicles and clear vesicles were increased in number and distributed throughout the cytoplasm (Fig. 2). Some rod-cored vesicles were located in the vicinity of the well-developed Golgi complex (Fig. 3). Almost no change was detected with respect to dense granules in pit cells.

Non-parenchymal cells in OK-432-treated rats showed approximately 2-fold higher percent cytotoxicity against YAC-1 cells compared with the control (Table 1). Treatment of non-parenchymal cells with anti-asialo $\mathrm{GM}_{1}$ plus comple-

Fig. 2 Details of close contacts between a pit cell (P) and a Kupffer cell (K). A striking increment of rodcored (arrows) and clear vesicles is the integral feature of the pit cell $36 \mathrm{~h}$ after the administration of OK-432. Phagocytic vacuoles (asterisks) are present in the Kupffer cell. $\times 30,000$

Fig. 3 High magnification micrograph of a pit cell showing the well-developed Golgi complex (Go) accompanied by rod-cored vesicles (arrows) $36 \mathrm{~h}$ after the $\mathrm{OK}-432$ injection. Microtubules (mt) radiate from the centriole (ce) located in the central area. $\times 45,000$ 

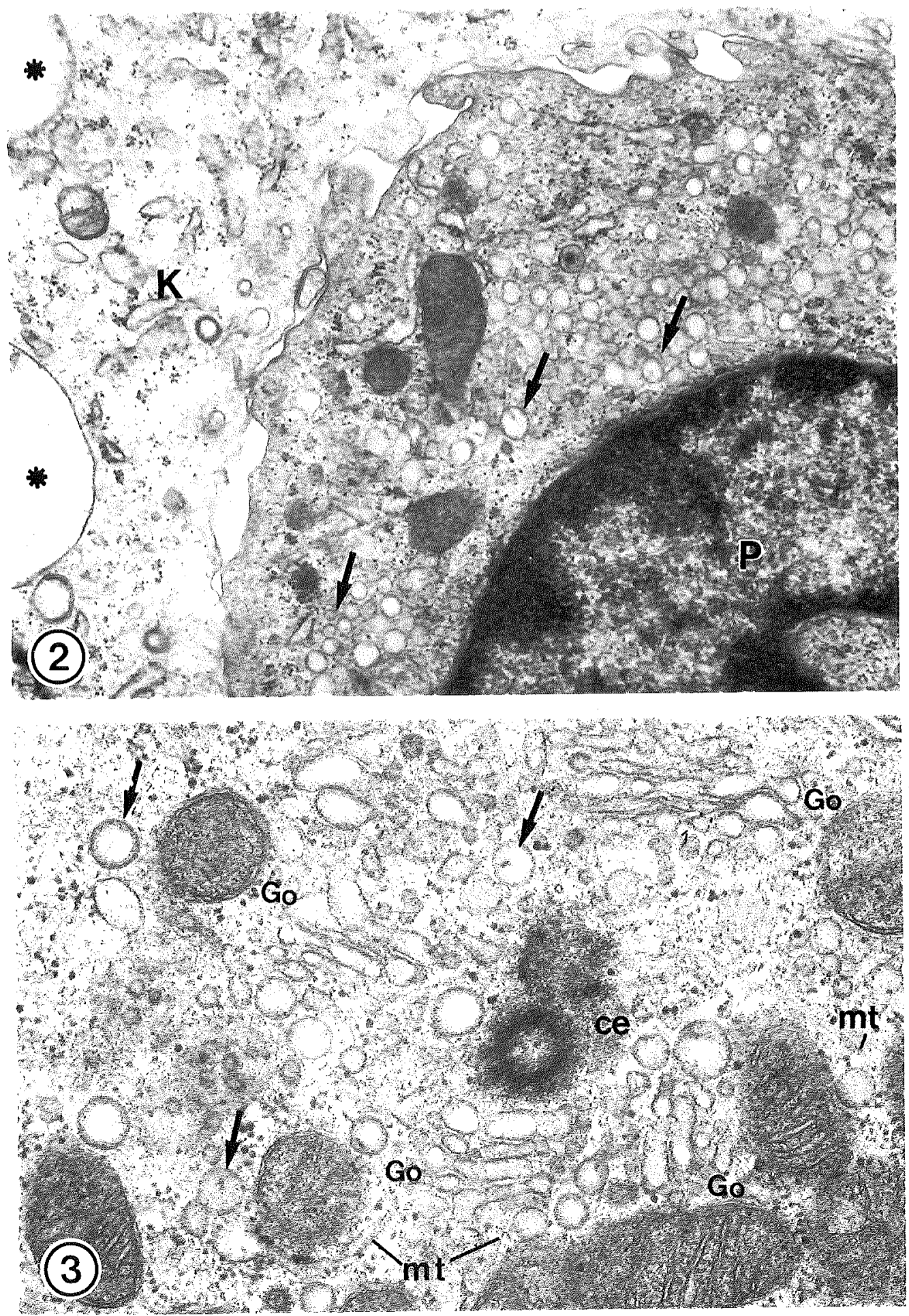

Figs. 2 and 3 
Table 1 Natural Killer Activity of Non-parenchymal Cells after the Administration of OK-432

\begin{tabular}{lcc}
\hline & \multicolumn{2}{c}{ Percent cytotoxicity } \\
& \multicolumn{2}{c}{ Effector to target ratio } \\
& $100: 1$ & $50: 1$ \\
\hline Control & 15.5 & 9.6 \\
OK-432* Experiment 1 & 31.5 & 22.8 \\
$\quad$ Experiment 2 & 33.4 & 19.4 \\
\hline
\end{tabular}

*OK-432 (5 KE) was administrated intravenously to rats $36 \mathrm{~h}$ before sacrifice. Non-parenchymal cells were isolated by collagenase perfusion methods, and incubated with ${ }^{51} \mathrm{Cr}-\mathrm{YAC}-1$ for $4 \mathrm{~h}$.

ment inhibited their ability to lyse YAC-1 cells by about $60 \%$. Since asialo $\mathrm{GM}_{1}$ is a specific surface marker of NK cells in the peripheral blood or spleen cells (9), the present data show that cytotoxic activity of the non-parenchymal cells in the rat liver is responsible for the function of NK cells.

The present findings showed that OK-432 stimulated not only the NK activity in the liver, but also the formation of rod-cored vesicles in pit cells. These vesicles were closely related to the prominent Golgi complex. We previously suggested that these vesicles were formed in the Golgi complex and that their contents were released extracellularly (7). This suggestion was based on observations that the thickness of the limiting unit-membrane of rod-cored vesicles was equal to that of the plasma membrane, and that they were present predominantly in the Golgi region and subplasmalemmal area, and apparently distinguishable from endocytotic vesicles. On the other hand, the cytotoxic process mediated by NK cells is essentially a secretory phenomenon associated with the release of cytolytic materials from secretory granules of the effector cells after signaling via the receptor on its surface membrane (3). The lytic activity of NK cells was mediated through a secretory pathway (2). Henkart et al. reported that cytoplasmic granules purified from rat large granular lymphocyte tumors were potentiated with the lytic activity against tumor target cells (4). We did not observe any appreciable changes in dense granules in pit cells from the OK-432-treated rat. We conclude that rod-cored vesicles mediate the NK activity by releasing their contents extracellularly, since OK-432 increases the liver NK activity and the increase is observed simultaneously with an increment of rod-cored vesicles in pit cells.
Received for publication 19 June 1985; and in revised form 24 July 1985

\section{REFERENCES}

1. Barlozzari T., Reynolds C. W. and Herberman R. B. (1983) In vivo role of natural killer cells: involvement of large granular lymphocytes in the clearance of tumor cells in anti-asialo $\mathrm{GM}_{1}$-treated rats. J. Immunol. 131, 1024-1027

2. Carpén O., Virtanen I. and SaKsela E. (1981) The cytotoxic activity of human natural killer cells requires an intact secretory apparatus. Cell. Immunol. 58, 97-106

3. Henkart M. P. and Henkart P. A. (1982) Lymphocyte-mediated cytolysis as a secretory process. In Mechanisms of Cell-mediated Cytotoxicity (ed. Clark W. R. and Goldstein P.) Plenum Publ. Co., pp. 227-242

4. Henkart P. A., Millard P. J., Reynolds C. W. and Henkart M. P. (1984) Cytolytic activity of purified cytoplasmic granules from cytotoxic rat large granular lymphocyte tumors. J. Exp. Med. 160, $75-93$

5. Herberman R. B., Djeu J. Y., Kay H. D., Ortaldo J. R., Riccardi C., Bonnard G. D., Holden H. T., Fagnani R., Santoni A. and Puccetti P. (1979) Natural killer cells; Characteristics and regulation of activity. Immunol. Rev. 44, 43-70

6. Kaneda K., Dan C. and WaKe K. (1983) Pit cells as natural killer cells. Biomedical Res. 4, 567-576

7. KANEDA K. and WAKE K. (1983) Distribution and morphological characteristics of the pit cells in the liver of the rat. Cell Tiss. Res. 233, 485-505

8. Kaneda K., WaKe K. and Senoo H. (1982) The 'rod-cored vesicle'; A new type of vesicle in the pit cells. In Sinusoidal Liver Cells (ed. KNOOK D. L. and WiSSE E.) Elsevier, Amsterdam, pp. 77-84

9. Kasai M., Iwamori M., Nagai Y., OKumura K. and TADA T. (1980) A glycolipid on the surface of mouse natural killer cells. Eur. J. Immunol. 10 , $175-180$

10. Oshimi K., Kano S., Takaku F. and Okumura K. (1980) Augmentation of mouse natural killer cell activity by a streptococcal preparation, OK-432. $J$. Natl. Cancer Inst. 65, 1265-1269

11. Rosenberg E. B., McCoy J. L., Green S. S., DonNelly F. C., Siwarski D. F., Levine P. H. and HerBERMAN R. B. (1974) Destruction of human lymphoid tissue-culture cell lines by human peripheral lymphocytes in ${ }^{51} \mathrm{Cr}$-release cellular cytotoxicity assays. J. Natl. Cancer Inst. 52, 345-352

12. SEgLen P. P. (1976) Preparation of isolated rat liver cells. Meth. Cell Biol. 13, 29-83

13. Talmadge J. E., Meyers K. M., Prieur D. J. and STARKEY J. R. (1980) Role of NK cells in tumour growth and matastasis in beige mice. Nature 284, 622-624

14. UCHIDA A. and Hoshino T. (1980) Clinical studies on cell-mediated immunity in patients with malignant disease. I. Effect of immounotherapy with OK-432 on lymphocyte subpopulation and phy- 
tomitogen responsiveness in vitro. Cancer 45 , 476-483

15. Wiltrout R. H., Mathieson B. J., Talmadge J. E., Reynolds C. W., Zhang S.-R., Herberman R. B. and Ortaldo J. R. (1984) Augmentation of organ-associated natural killer activity by biological response modifiers. Isolation and characteriza- tion of large granular lymphocytes from the liver. J. Exp. Med. 160, 1431-1449

16. Wisse E., VAN't Noordende J. M., VAN der MeULEN J, and DAEMS W. TH. (1976) The pit cell: Description of a new type of cell occurring in rat liver sinusoids and peripheral blood. Cell Tiss. Res. 173, 423-435 